\title{
Simulation of the Runoff in a Short-Term Scale and Assessing the Hydrologic Effects of Climate Change in the Zarinerood Basin (As Part of the Orumyeh Lake Great Basin)
}

\section{Mohammad Seyedielmabad ${ }^{*}$}

Department of Natural Resources and Marine Sciences, Tarbiat Modares International University, Iran

"Corresponding author: Mohammad Seyedielmabad, Department of Natural Resources and Marine sciences, Tarbiat Modares International University, Iran, Tel: +98 09398607791; E-mail: msaedi1225@gmail.com

Rec date: Feb 11, 2016; Acc date: Mar 14, 2016; Pub date: May 19, 2016

Copyright: ( 2016 Seyedielmabad M, et al. This is an open-access article distributed under the terms of the Creative Commons Attribution License, which permits unrestricted use, distribution, and reproduction in any medium, provided the original author and source are credited.

\begin{abstract}
Snowmelt has a significant effect on rivers outflow in Western Iran. Occasionally, in some areas about $90 \%$ of runoff result from melting snow. Access to accurate and timely information for measuring the volume of available water resources is necessary. It is important to plan and design programs for drought-resistance and flood prevention as fundamental issues in Iran. The water balance (WB) model was used to estimate daily runoff produced by melting snow, without reliance to satellite images, from October to February (2005-2006) in the Zarinerood basin. This model uses available data and information in the basin to provide the possibility of estimating daily runoff in the short-term. For this purpose, the watershed was divided into three elevation zones and in each zone, an index station was determined. Using the water balance model, runoff was estimated from each station producing the outlet runoff in the basin. To calculate model accuracy, the correlation coefficient $\left(R^{2}\right)$ and root mean square error (RMSE) were estimated as 0.62 and 0.003 , respectively. These results showed that the accuracy of the model to estimate daily runoff was acceptable. Therefore, the calibration of this model endorses its use in similar basins. It has been shown that increasing temperature has affected on snow-melt period as shifting it from spring and early summer to winter in North-west Iran. It results to increasing runoff rates in the snow-melt season and therefore this region encounters intensive drought and flood.
\end{abstract}

Keywords: Simulation; Runoff; Hydrologic effects; Climate change; Zarinerood basin

\section{Introduction}

Water is regarded as the most essential of the world's natural resources [1]. Water perhaps is the most valuable natural asset in the Middle East [2]. The Zarinerood basin is largely fed from snow precipitation of which nearly two-thirds occurs in the winter and may remain as snow itself for the remaining part of the year. Accordingly, runoff modeling in the mountainous regions of Western Iran, one of the major headwaters of Zarinerood basin, has significant importance when forecasting snowmelt discharge, especially for energy production, flood control, irrigation and optimization of reservoir operation. One common problem that scientists encounter in developing nations is the lack of informative data for the related study [3]. Even if such data existed, quick, on-line and timely access to the data may be problematic. As Iran is a developing country, prompt access to snow data, which is essential in the analysis of the relationships between climatic and topographic factors with snowpack, is not yet possible. Governmental organizations most often perform the snow measurements of snow courses mostly on a monthly basis. In these snow courses, the snow water equivalent from snow depths are measured along a track. Iran can be described as a country with abundant snow; however, an established continuous operational snow monitoring system is not available. There exist some individual studies such as Ref. [4] and Pourhmmat et al. [5]. Increasing concentrations of greenhouse gases in the atmosphere are predicted to result in an increase in global mean temperature of the order of $0.3^{\circ} \mathrm{C}$ per decade, in the absence of preventive strategies [6]. Such a global warming could have a significant impact upon hydrological and water resources systems [6].

Due to greenhouse gas emissions most region of the earth are expected to experience significant increases in mean annual temperature (i.e., $>2^{\circ} \mathrm{C}$ ) by the end of the present century [7]. At present, most forecasts for the effect of climate change on runoff are largely based on regionalized global circulation models (GCMs) [8]. Depending on the scenario for greenhouse gas emissions assumed for the model, the GCM outputs scenarios for temperature and precipitation, the latter of which is far more uncertain than the former [8]. These uncertainties are then propagated into the distributed or lumped parameter hydrologic model used to predict runoff [8]. These hydrologic models in turn usually require calibration and validation against historical climatic and discharge data before it can be used to forecast runoff under a particular GCM scenario [8,9]. A monthly water balance (WB) model was developed for the Yukon River Basin (YRB) by Hay and McCabe [10]. In that study, potential hydrologic effects of climate changes were assessed for the YRB by imposing changes in precipitation and temperature derived from selected Intergovernmental Panel for Climate Change (IPCC) climate simulations. This model has been used in numerous studies and provides reliable estimates of monthly runoff for locations across a range of climatic conditions [11]. One of the possible solutions for the estimation of snowpack spatial distribution is in relation to the changes in the snowpack specifications affected by changes the factors that influence on. The climatic factors are more effective factors on the snowpack. As climate was identified as an effective factor on the snowpack, thus temperature and rainfall were selected among the climatic factors, 
Citation: Seyedielmabad M (2016) Simulation of the Runoff in a Short-Term Scale and Assessing the Hydrologic Effects of Climate Change in the Zarinerood Basin (As Part of the Orumyeh Lake Great Basin). Hydrol Current Res 7: 230. doi:10.4172/2157-7587.1000230

Page 2 of 6

which play greater importance more than the other factors by Seyedielmabad and Moradi [12] in the northwest of Iran.

This paper reports on works carried out to simulate runoff using the short-term scale water balance (WB) model in the Zarinerood Basin. Its objectives are threefold:

To assess the water balance model in runoff simulation on a shortterm in the Zarinerood basin;

To determine the influence of different elevation areas in the basin on snow cover thereby determining their effect in producing runoff in the basin outlet;

To assess the hydrologic effects of climate change in this region.

It is believed that the results presented herein will be of use in the development of short-term scale to simulate the runoff in the basins by providing an indication of how short-term scale variability could influence simulation of the runoff in long-term simulation and how climate variability, especially temperature changes effect on runoff.

\section{Study Area}

The study area is chiefly limited to the Zarinerood basin (Figure 1), which is the headwater of the Zarinerood River. The basin is located in the North-west region of Iran and South-east of Orumiyeh Lake at longitude 45-45V03W to 47-15V28 W East and latitudes 35-30V18 W to $36-45 \mathrm{~V} 26 \mathrm{~W}$ North. The basin has a drainage area of $13890 \mathrm{~km}^{2}$ with an elevation ranging from 1300 to $3700 \mathrm{~m}$.

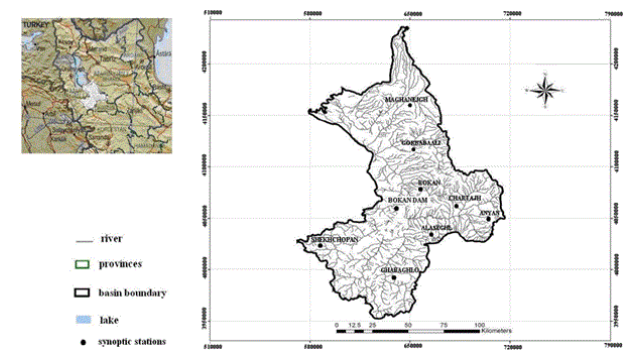

Figure 1: Location of Zarinerood basin (southeast of Orumiyeh Lake) in Iran and the location of synoptic stations and SNOTEL in the basin, Bokan dam location are shown in the basin.

\section{Methodology and Data}

The water balance $(\mathrm{WB})$ model uses an accounting procedure the allocation of water among various components of the hydrologic system [13-15]. The WB model includes the concepts of climatic water supply and demand, seasonality in climatic water supply and demand, snow accumulation and melt, and soil-moisture storage $[14,15]$. The elevation range of the basin is visible from the digital elevation model (Figure 2). Spatial analysis operations were performed using the Arc GIS 9.2 software which converts analog topography maps to a digital format; by generating the digital elevation model and extracting the basin boundary. Long-term studies indicate that about $60-70 \%$ of the total annual volume of water comes during the snow-melt season. In the Zarinerood basin, one big dam, the Bokan dam, is designed for flood control, hydropower generation, irrigation and water supply (Figure 1). Thus, an accurate estimation of runoff is very important in this area of interest. The measurements of the snow course made by government organizations in the Western part of Iran were also used in the analysis. Using the digital elevation model, this basin was divided into three elevation zones (Figure 3) where an index station was determined in each zone (Table 1). Some features of each index station are shown in Table 2. Runoff was estimated using the water balance (WB) model in each station. Outlet runoff in the basin was determined by sharing each zone on producing the outlet runoff in the basin [16]. The water balance (WB) model is shown in Eq. (1).

$$
R+M-\frac{d S M S_{U}}{d t}-\frac{S M S_{I}}{d t}-A E T=Q_{S}+Q_{d}=Q_{r} \text { Eq. (1) }
$$

where $\mathrm{R}$ is precipitation in $\mathrm{mm} /$ day, SMS is soil moisture storage in $\mathrm{m}^{3} /$ day, I and $U$ are up and down layers of soil, respectively; AET is actual evapotranspiration in $\mathrm{mm}$ /day and $\mathrm{Qr}$ is runoff in $\mathrm{mm} /$ day. $\mathrm{M}$ is snow melt water in $\mathrm{mm}$ /day and is given by

\section{$\mathrm{M}=\mathrm{Cm}$ (Tair-Tmelt) Eq. (2)}

Where $\mathrm{M}$ is the daily mean snow melt $(\mathrm{mm})$ and $\mathrm{Cm}$ is the degree day factor $\left(\mathrm{mm} /{ }^{\circ} \mathrm{C}\right.$ per day) as well as Tair is daily ambient temperature $\left({ }^{\circ} \mathrm{C}\right)$ and Tmelt is the threshold melt temperature $\left({ }^{\circ} \mathrm{C}\right)$ [16]. The critical melt temperature is often set to zero and was therefore set to zero in this basin [16]. In the water balance model, AET is daily actual evapotranspiration ( $\mathrm{mm} /$ day) and is given by

$$
\mathrm{AET}=\mathrm{Kc} \times \text { ETPc Eq. (3) }
$$

ETP is the daily potential evapotranspiration in $\mathrm{mm}$ /day which can be computed by several different temperature-based methods as it strongly correlates with temperature (T) [8]. The climate of western Iran is arid and semi-arid and as such, ETP is estimated by BlanneyCriddle model as shown in Eq. (4) [17].

$$
\mathrm{ETP}=\mathrm{P}(0.46 \mathrm{~T}+8.13) \text { Eq. (4) }
$$

Where $\mathrm{P}$ is light coefficient or daily mean light hours percent for each month (Table 3 ), $\mathrm{T}$ is the daily mean temperature $\left({ }^{\circ} \mathrm{C}\right)$. Figure 4 shows the modified ETP [17]. In the western Iran ETPc is computed with relative mean humidity of $20-50 \%$, daily mean wind speed of $2-5$ $\mathrm{m} / \mathrm{s}$ and proportion of measured sunny hours (n) divided by average day length in a month $(\mathrm{N}), \mathrm{n} / \mathrm{N}=0.7$. In the Zarinerood basin, more than $40 \%$ of the land cover is ranges and therefore $\mathrm{Kc}$ is acquired via Table 4. Soil moisture storage (SMS) depends on features such as soil layers, soil texture and water base flow in the basin zones. The daily runoff (Qr) was estimated from index stations and outlet runoff was determined based on the incorporation of each zone in producing snow melt runoff in the basin.

\begin{tabular}{|l|l|l|l|}
\hline Zone number & Elevation range & Index station & percent in the basin \\
\hline 1 & $1300-1800$ & Saghez & 35.3 \\
\hline 2 & $1800-2400$ & Tekab & 49.1 \\
\hline 3 & $2400-3700$ & Zarine and Bijar & 15.5 \\
\hline
\end{tabular}

Table 1: Some features of the specific zones. 
Citation: Seyedielmabad M (2016) Simulation of the Runoff in a Short-Term Scale and Assessing the Hydrologic Effects of Climate Change in the Zarinerood Basin (As Part of the Orumyeh Lake Great Basin). Hydrol Current Res 7: 230. doi:10.4172/2157-7587.1000230

Page 3 of 6

\begin{tabular}{|l|l|l|l|}
\hline Index station & Elevation & Longitude & Latitude \\
\hline Saghez & 1522.8 & $4616^{\prime}$ & $365^{\prime}$ \\
\hline Tekab & 1765 & $477^{\prime}$ & $3623^{\prime}$ \\
\hline Zarine & 2142.6 & $4655^{\prime}$ & $364^{\prime}$ \\
\hline
\end{tabular}

Table 2: Some characteristics of the index stations.

\begin{tabular}{|l|l|l|l|l|l|}
\hline Latitude & October & November & December & January & February \\
\hline 44 & $0 / 25$ & $0 / 22$ & $0 / 20$ & $0 / 21$ & $0 / 24$ \\
\hline 42 & $0 / 25$ & $0 / 22$ & $0 / 21$ & $0 / 21$ & $0 / 24$ \\
\hline 40 & $0 / 25$ & $0 / 22$ & $0 / 21$ & $0 / 22$ & $0 / 24$ \\
\hline 35 & $0 / 25$ & $0 / 23$ & $0 / 22$ & $0 / 23$ & $0 / 25$ \\
\hline 30 & $0 / 26$ & $0 / 24$ & $0 / 23$ & $0 / 24$ & $0 / 25$ \\
\hline 25 & $0 / 26$ & $0 / 25$ & $0 / 24$ & $0 / 24$ & $0 / 26$ \\
\hline
\end{tabular}

Table 3: The mean percent of daily light time in the different months and the latitudes from October to February.

\begin{tabular}{|l|l|l|l|l|l|l|l|l|l|l|l|}
\hline $\begin{array}{l}\text { The } \\
\text { percent of } \\
\text { products } \\
\text { The type of } \\
\text { products }\end{array}$ & $\mathbf{0}$ & $\mathbf{1 0}$ & $\mathbf{2 0}$ & $\mathbf{3 0}$ & $\mathbf{4 0}$ & $\mathbf{5 0}$ & $\mathbf{6 0}$ & $\mathbf{7 0}$ & $\mathbf{8 0}$ & $\mathbf{9 0}$ & $\mathbf{1 0 0}$ \\
\hline Dry farm & $20 \%$ & $\begin{array}{l}20 \\
\%\end{array}$ & $\begin{array}{l}21 \\
\%\end{array}$ & $\begin{array}{l}26 \\
\%\end{array}$ & $\begin{array}{l}39 \\
\%\end{array}$ & $\begin{array}{l}55 \\
\%\end{array}$ & $\begin{array}{l}66 \\
\%\end{array}$ & $\begin{array}{l}78 \\
\%\end{array}$ & $\begin{array}{l}92 \\
\%\end{array}$ & $1 \%$ & $1 \%$ \\
\hline $\begin{array}{l}\text { Watered } \\
\text { farm }\end{array}$ & $20 \%$ & $\begin{array}{l}20 \\
\%\end{array}$ & $\begin{array}{l}20 \\
\%\end{array}$ & $\begin{array}{l}22 \\
\%\end{array}$ & $\begin{array}{l}31 \\
\%\end{array}$ & $\begin{array}{l}41 \\
\%\end{array}$ & $\begin{array}{l}51 \\
\%\end{array}$ & $\begin{array}{l}62 \\
\%\end{array}$ & $\begin{array}{l}70 \\
\%\end{array}$ & $\begin{array}{l}76 \\
\%\end{array}$ & $\begin{array}{l}78 \\
\%\end{array}$ \\
\hline Forest & $20 \%$ & $\begin{array}{l}20 \\
\%\end{array}$ & $\begin{array}{l}20 \\
\%\end{array}$ & $\begin{array}{l}20 \\
\%\end{array}$ & $\begin{array}{l}23 \\
\%\end{array}$ & $\begin{array}{l}32 \\
\%\end{array}$ & $\begin{array}{l}42 \\
\%\end{array}$ & $\begin{array}{l}55 \\
\%\end{array}$ & $\begin{array}{l}70 \\
\%\end{array}$ & $\begin{array}{l}85 \\
\%\end{array}$ \\
\hline Range & $30 \%$ & $\begin{array}{l}30 \\
\%\end{array}$ & $\begin{array}{l}30 \\
\%\end{array}$ & $\begin{array}{l}50 \\
\%\end{array}$ & $\begin{array}{l}75 \\
\%\end{array}$ & $\begin{array}{l}90 \\
\%\end{array}$ & $\begin{array}{l}98 \\
\%\end{array}$ & $1 \%$ & $1 \%$ & $1 \%$ & $1 \%$ \\
\hline
\end{tabular}

Table 4: The Kc coefficients in the water balance model.

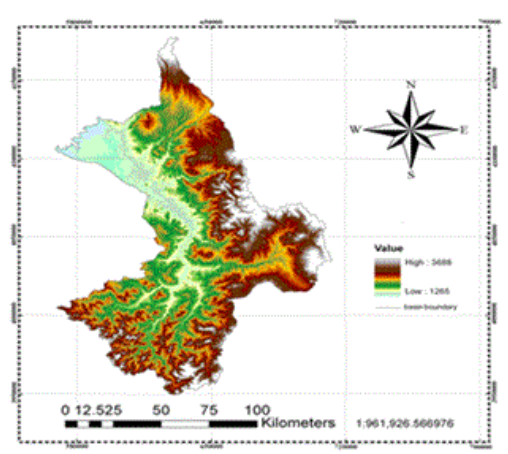

Figure 2: Elevation range in digital elevation model (DEM) in the Zarinerood basin.

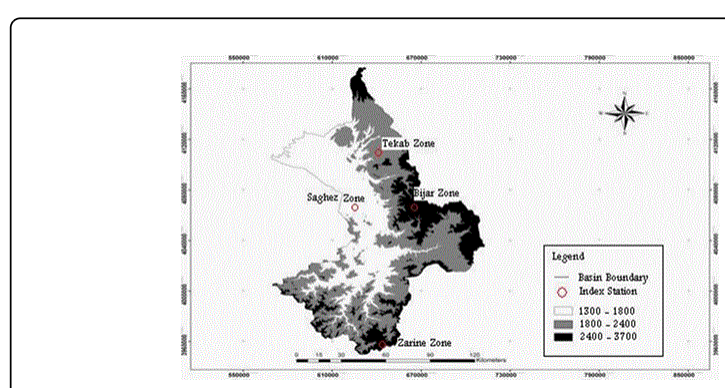

Figure 3: The elevation ranges in the Zarinerood basin.

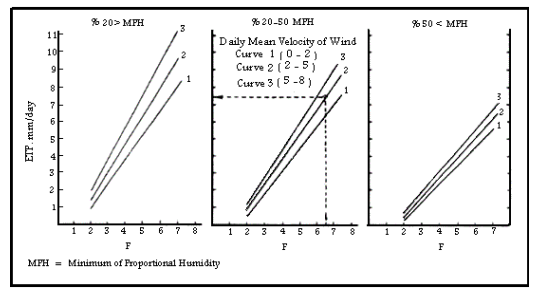

Figure 4: Diagram of modify the potential evapotranspiration for mean day length $(\mathrm{n} / \mathrm{N}=0.7)$.

\section{Calibration of the Water Balance Model against 2005-2006 Data}

As the first step in model application, the water balance model was calibrated and evaluated parameters from the synoptic station at the basin outlet. Preliminary sensitivity analysis was carried out on the data set, in order to obtain an appreciation of model response to changing parameter values [18]. The model was then calibrated to 
Citation: Seyedielmabad M (2016) Simulation of the Runoff in a Short-Term Scale and Assessing the Hydrologic Effects of Climate Change in the Zarinerood Basin (As Part of the Orumyeh Lake Great Basin). Hydrol Current Res 7: 230. doi:10.4172/2157-7587.1000230

Page 4 of 6

degree-day factor recorded at the synoptic station during the snow melt season.

\section{Evaluation and Validation of the Water Balance Model against 2005-2006 Data}

The performance of the calibrated model was evaluated using data from the melt season. Model evaluation was carried out using correlation coefficient $\left(\mathrm{R}^{2}\right)$ that is shown in Eq. (5).

$$
R^{2}=1-\frac{\sum_{i=1}^{n}\left(Q_{i}-Q_{i}^{\prime}\right)^{2}}{\sum_{i=1}^{n}\left(Q_{i}-\vec{Q}\right)^{2}} \text { Eq. (5) }
$$

Where Qi is the observed runoff and Qi' is simulated runoff in $\mathrm{mm}$ / day; is the mean runoff and $\mathrm{n}$ is the number of days in a melt season. Validation of the water equilibrium model was carried out using root mean square (RMSE) shown in Eq. (6).

$$
R M S E=\sqrt{\frac{1}{n} \sum_{i=1}^{n}\left[z\left(x_{i}\right)-\hat{z}\left(x_{i}\right)\right]^{2}} \text { Eq. (6) }
$$

Where is the observed runoff and is simulated runoff in $\mathrm{mm} /$ day and $\mathrm{n}$ is the number of days in a melt season.

\section{Results}

Preliminary sensitivity analysis indicated that the model was most sensitive to degree-day factor $(\mathrm{Cm})$ in the snow-melting water equation. The value of the correlation coefficient $\left(\mathrm{R}^{2}=0.62\right)$ indicated that the runoff simulation using the water balance model was reasonable. Also, the root mean square error (RMSE) of 0.003 showed that the accuracy of the model was acceptable. These conclusions were presented by Semadeni [16] on the simulation of snow melt runoff in Valuoja and Gimdalsbyn basins with the water balance model in October to February. In that study, the correlation coefficient $\left(R^{2}\right)$ acquired for two basins were 0.85 and 0.55 , respectively. With those results, the simulation of runoff in Valuoja basin was better than Gimdalsbyn basin in the same model. The comparison between simulated runoff and observed runoff hydrograph in the Zarineroood basin is shown in Figure 5. The diagram of correlation between simulated runoff $(\mathrm{mm} /$ day) and the observed runoff $(\mathrm{mm} /$ day) correlates with the results of correlation coefficient in this basin (Figure 6). Melting and further crystallization of the snow crystals were intensely affected by temperature changes and thus, the snow density affected the melting and further crystallization. Seyedielmabad and Moradi [12] indicated that in the northwest of Iran, from the 3 months of study only five rainy days were recorded; therefore, the amount of rainfall had no significant correlation with the snowpack specificities but the relationships between some climatic factors with snowpack specifications were obtained, which showed significant correlation only between the components of daily temperature and snow density. Also, in that study the relationship between some climatic factors and the daily discharge of the snowmelt runoff showed significant correlations between the maximum med temperature in $1 \%$ surfaces and the medium and absolute maximum temperature in 5\% surfaces with snowmelt runoff. Consequently these researchers showed that the amounts of snowpack depth have significant correlations with the height of the stations and the height classes in $1 \%$ surface and snowpack depths showed significant differences together within the different height classes. The elevation of Zarine- Bijar zone is higher than other zones therefore snow cover remains up to early spring in this region. The area of this zone is low therefore its contribution in producing the runoff is low. Snowfall scarcely occurs with the increasing the temperature in the low elevations and snow cover remains in short-period as the Saghez zone has these conditions in this basin. Due to extent and duration of snow in the Tekab zone, the contribution of this zone in producing the runoff is high. The influence of this zone in outlet runoff is further than other zones in this basin. Overall, by increasing temperature and decreasing snow duration, the runoff rate was lastly increased in the Zarineroood basin and therefore in the Orumiyeh Lake basin in the snow-melt season (Figure 7). Consequently, streamflows were intensively decreased after snow-melt season whereas more than two-third of water surface was subsided and this region encounter to the drought (Figure 8). The rate of subsidence in the Zarineroood river level was $1.7 \mathrm{~m}$ between last March and early July in 2015 (Figure 9).

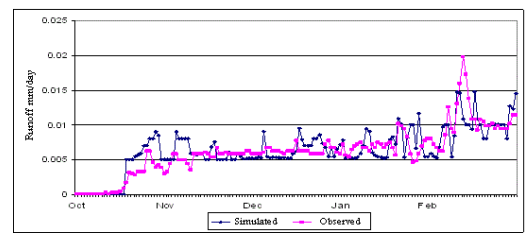

Figure 5: Comparison between the simulated runoff ( $\mathrm{mm} /$ day) and observed runoff hydrograph $(\mathrm{mm} /$ day) in the outlet station from Zarineroood basin.

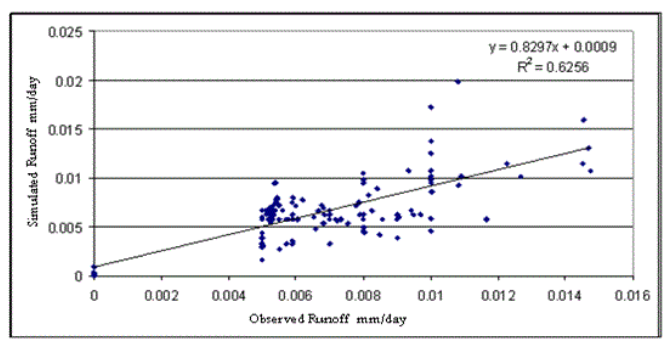

Figure 6: Correlation between the simulated (mm/day) and observed discharge $(\mathrm{mm} /$ day) of runoff in the outlet station from Zarineroood basin.

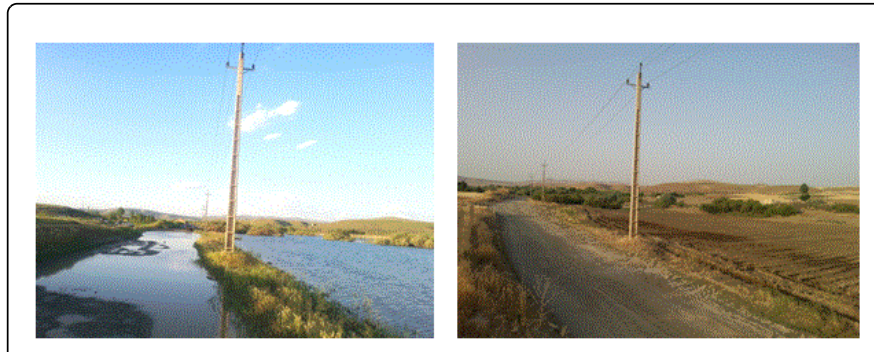

Figure 7: Zarineroood River overflow in the last snow-melt period in early March in 2015, the road and farmlands were sunk by flood and its condition after snow-melt period in last June in 2015 . 
Citation: Seyedielmabad M (2016) Simulation of the Runoff in a Short-Term Scale and Assessing the Hydrologic Effects of Climate Change in the Zarinerood Basin (As Part of the Orumyeh Lake Great Basin). Hydrol Current Res 7: 230. doi:10.4172/2157-7587.1000230

Page 5 of 6
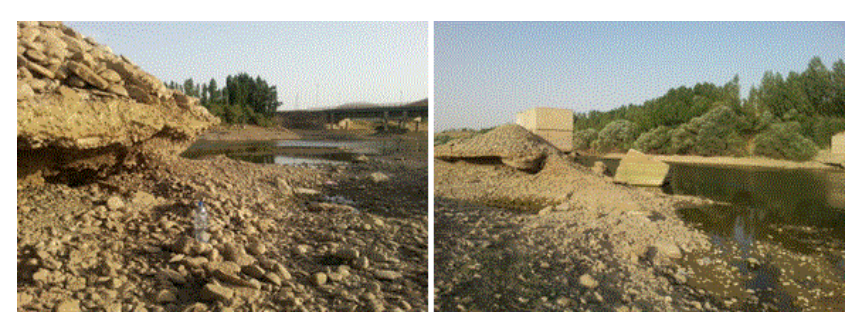

Figure 8: Subsidence of the Zarineroood River after snow-melt period in last June in 2015 and the river subsidence rate is obvious.
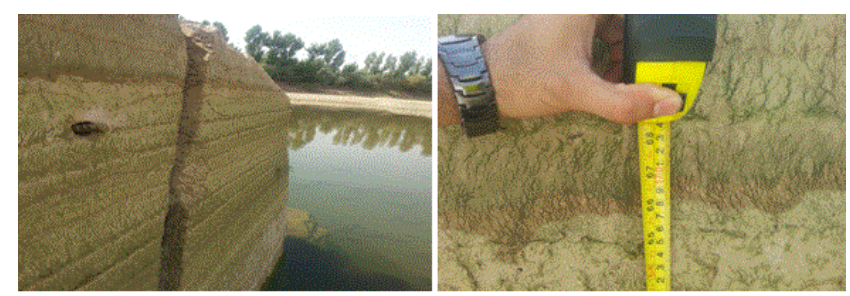

Figure 9: Subsidence in the Zarineroood River after snow-melt period in early July in 2015 and the subsidence rate was measured.

\section{Discussion and Conclusions}

Considering the importance of the Tekab zone in the Zarinerood basin by its contribution in producing runoff in the basin outlet than other zones, it is necessary to monitor and manage snow cover and runoff in this zone especially during October to February. In this basin, snowmelt started unusually early, in mid- October, as the great part of snow melted along October to February in 2005-2006. Snowmelt accelerated in last January and maximum melting snow occurred in mid- February. It is likely that wherever increases in continental precipitation occur, they will lag increases in air temperature [8]. As a result of associated warming of the oceans, and their arial expansion via sea-level rise, it is also expected that there will eventually be an overall increases in continental precipitation because of great evaporation from the oceans [18], with general increases of $10-20 \%$ at latitudes above 450 and within 50 of the equator but with decreases of $5-20 \%$ between latitudes of 5 and 400 [7].
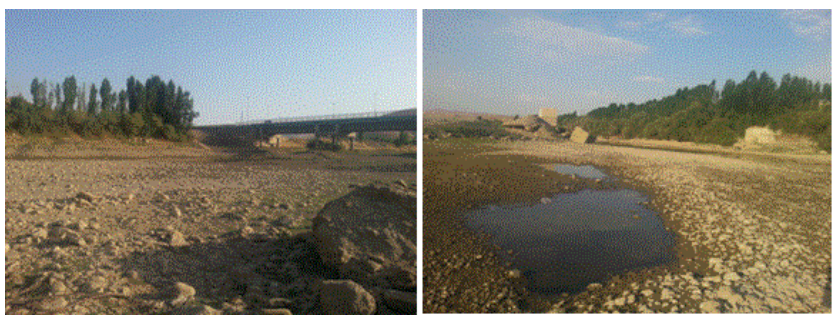

Figure 10: The Zarineroood River was dried in mid- July in 2015.

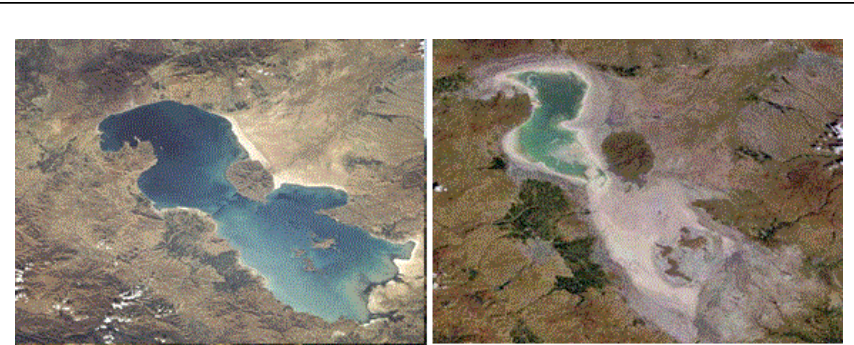

Figure 11: Satellite images of Orumiyeh Lake in October 2003 and in September 2014.

Already in the Zarinerood basin, nearly two- thirds snow precipitation had occurred in the winter and might remain as snow itself for one-half of the year. Most of the runoff occurred in spring and early summer. Lastly, because of increasing climate warming, most of the snow melts in winter. As a result, snow had disappeared from the meteorological station by early March, immediately prior to the beginning of the field season. Seyedielmabad and Moradi [12] indicated that the values recorded of the components of daily temperature in the northwest of Iran showed a significant correlation with the snowpack density in $1 \%$ surface, whereas significant correlation was observed with the other snowpack specificities. Also, in that study using IRS and MODIS satellite images and therefore snow cover maps, extracted from these images in 2006-2007, was shown that snow had disappeared by last March in this region. Consequently the results of the linear and positive relationship existing between snowpack depth $(\mathrm{cm})$ and elevation $(\mathrm{m})$ was in accordance with the results. Therefore, in this study, the results of the simulation of runoff are in accordance with the results of Semadeni [16] and Seyedielmabad et al. [12]. In the Orumiyeh Lake basin, increasing temperature was associated with decreasing precipitation during fifty years ago. These factors have shifted the timing of snow-melt runoff from spring and early summer to winter in this region. Results from the study by Hay and McCabe in the Yukon River Basin (YRB) [10] reported an increase in annual runoff over the twenty-first century for the YRB with increase in precipitation having the greatest effect on increases in runoff. The WB model shows close agreement with the measured data. Climate changes have occurred in one-half of the last century which has altered the conditions of the environment and ecosystem from semi-humid to arid and semi-arid in the Orumiyeh Lake basin as the Zarineroood River was dried in mid- July in 2015 (Figure 10). Because of climate changes and irregular water utilization in agriculture and industry, the Orumiyeh Lake has been lost more than two-third of own water (Figure 11). Lastly, the great volume of particles in the air has invaded this region from South-west Iran in most days of the year (Figure 7). These particles intensively affect regional air temperature and accelerate climate changes. These problems will threaten the environment, wildlife and human life in western Iran in the close future (Table 5).

\begin{tabular}{|l|l|l|l|l|l|}
\hline Month & October & November & December & January & February \\
\hline Degree-day factor & 0.18 & 0.21 & 0.223 & 0.24 & 0.34 \\
\hline
\end{tabular}

Table 5: The best fit value of degree-day factor for calibrated simulation from October to February. 
Citation: Seyedielmabad M (2016) Simulation of the Runoff in a Short-Term Scale and Assessing the Hydrologic Effects of Climate Change in the Zarinerood Basin (As Part of the Orumyeh Lake Great Basin). Hydrol Current Res 7: 230. doi:10.4172/2157-7587.1000230

Page 6 of 6

\section{Acknowledgements}

The authors feel grateful to the Iran Water Resources Management Organization, spatial organization and army geographic organization of Iran to give maps and information of climate, hydrometrics and snowtel to us. Also the authors feel grateful to Water Resources Management Organization of West Azarbaijan province.

\section{References}

1. Vorosmarty CJ, McIntyre PB, Gessner MO (2010) Global threats to human water security and river biodiversity. Nature 467: 555-561.

2. Nagler T, Rott H, Malcher P, Müller F (2007) Assimilation of meteorological and remote sensing data forecasting. Remote Sensing of Environment 112: 1408-1420.

3. Tekeli AE, Rekb ZA, Sormanc AA, Sensoyc A, Sorman AU (2005) Using MODIS snow cover maps in modelling snowmelt runoff process in the eastern part of Turkey. Remote Sensing of Environment 97: 216-230.

4. Ghanbarpour MR, Saghafian B, Saravi MM, Abbaspour KC (2007) Evaluation of spatial and temporal variability of snow cover in a large mountainous basin in Iran. Nordic Hydrology 38: 45-58.

5. Pourhmmat J, Saghafian B, Sedghi H (2004) An algorithm to map snow, cloud and land in NOVAA AVHHR data: formulation, verification and evaluation. In: Proceeding of the Fourth International Iran \& Russia Conference, pp: 1258-1264.

6. Arnella NW, Reynard NS (1995) The effects of climate change due to global warming on river flows in Great Britain. Journal of Hydrology 183: 397-424.

7. IPCC (2007) Climate change the physical science basis. In: Solmon S, Qin D, Manning M (Eds.), Contribution of Working Group I to the fourth Assessment Report of the Intergovernmental Panel on Climate Change.

8. Gardner LR (2009) Assessing the effect of climate change on the mean annual runoff. Journal of hydrology 379: 351-359.
9. Jiang T, Chen YD, Xu C, Single VP (2007) Comparison of hydrological impacts of Climate change simulated by six hydrological models in the Dongjiang Basin, South China. Journal of Hydrology 336: 316-333.

10. Hay LE, McCabe GJ (2010) Hydrologic effects of climate change in the Yukon River Basin. J Climate Changes 100: 509-523.

11. McCabe GJ, Wolock DW (2008) Joint variability of global runoff and global sea-surface temperatures. J Climate 9: 816-824.

12. Seyedielmabad M, Ghanbarpour MR, Moradi HR (2015) Snow cover mapping using multispectral and multi-temporal IRS-P6 AWiFS data and the relationships between some climatic and topographic factors with snowpack in the northwest of Iran. Journal of water and climate change, IWA Publishing.

13. McCabe GJ, Wolock DW (1999) Future snowpack conditions in the western United States derived from general circulation model climate simulations. J Am Water Resour Assoc 35: 1473-1484.

14. Wolock DW, McCabe GJ (1999) Simulated effects of climate changes on mean annual runoff in the conterminous United States. In: Adams DB (ed.). Proceeding of specialty conference on potential consequences of climate variability and change to water resources of the United States, 10-12 May 1999. Alanta, Georgia: American Water Resources Association, pp: 161-164.

15. McCabe GJ, Markstrom SL (2007) A monthly water-balance model driven by a graphical user interface. USGS open-file report: 2007-1088, p: 6.

16. Semadeni DA (1997) Monthly Snowmelt modeling for large-scale climate change studies using the degree day approach. Ecological modeling 101: 303-323.

17. Ward AD, Trimble SW (2004) Environmental Hydrology, p: 475.

18. Loftgren BM (2004) Global warming effects on Great Lakes water: more precipitation but less water?. In: Proceeding, 18th Conference on hydrology, 8th Annual Meeting of the American Meteorology Society, Seattle, WA, USA, January 11-15, p: 3. 